\title{
LICZBY KRYTERIALNE W CHARAKTERYSTYCE WĘŻOWNICOWEGO WYMIENNIKA CIEPLA
}

\begin{abstract}
W artykule zaprezentowano przegląd literaturowy oraz analizę porównawczą dotyczącą liczb kryterialnych istotnych w opisie i projektowaniu wężownicowych wymienników ciepła - liczby Deana i krytycznej liczby Reynoldsa. Liczby te uwzględniają specyfikę przepływu płynu w wężownicy powstałej przez nawinięcie rury o przekroju kołowym na walcowej pobocznicy. Omówiono również geometrię wężownicy niezbędną w opisie liczb kryterialnych ze względu na istotny wpływ parametrów geometrycznych na strukturę przepływu. Dokonana analiza porządkuje zakresy stosowalności odpowiednich wzorów kryterialnych w zastosowaniu do opisu zjawisk związanych z intensyfikacją wymiany ciepła w wężownicowym wymienniku, wynikającą z pojawienia się przepływu wtórnego, który jest efektem interakcji siły odśrodkowej, sił bezwładności oraz sił wywołanych lepkością płynu.
\end{abstract}

Słowa kluczowe: wężownica, liczba Deana, krytyczna liczba Reynoldsa

\section{Wprowadzenie}

Wymienniki ciepła należą do ważnej grupy urządzeń, których zadaniem jest przekazywanie ciepła pomiędzy różnymi czynnikami. Zastosowanie wymienników jest bardzo szerokie, dlatego też są one powszechnie spotykane w różnego rodzaju systemach technicznych. Istnieje bardzo dużo rozwiązań konstrukcyjnych wymienników ciepła. Jednym z rodzajów jest wężownicowy wymiennik ciepła. Wężownica to podstawowy element wężownicowych i spiralnych wymienników ciepła, które ze względu na zwartą budowę i dużą intensywność transportu ciepła znajdują powszechnie zastosowanie w energetyce, przemyśle elektronicznym, chemicznym, rolno-spożywczym, chłodnictwie, układach odzysku ciepła itp.

Intensyfikacja wymiany ciepła w wymiennikach wężownicowych jest spowodowana interakcją pomiędzy siłą odśrodkową, siłą bezwładności oraz siłą wywołaną lepkością. Siły te przyczyniają się do powstawania przepływu wtórnego. W najprostszej konfiguracji wężownice są wykonywane przez nawinięcie rury

\footnotetext{
1 Autor do korespondencji/corresponding author: Robert Smusz, Politechnika Rzeszowska, 35-959

Rzeszów, al. Powstańców Warszawy 12, tel. (17) 8651242, e-mail: robsmusz@prz.edu.pl

2 Joanna Wilk, Politechnika Rzeszowska, e-mail: joanwilk@prz.edu.pl
} 
o przekroju kołowym na walcowej pobocznicy. Zdarzają się też rozwiązania konstrukcyjne, w których wężownice są wykonywane przez nawinięcie np. rury o przekroju owalnym na pobocznicy stożka. Na strukturę przepływu, straty ciśnienia płynu w wymiennikach wężownicowych i spiralnych istotny wpływ mają parametry geometryczne.

\section{Geometria wężownicy}

Do analizy zagadnień cieplno-przepływowych w wężownicy jest niezbędne przedstawienie charakterystyki geometrycznej wężownicy. Podstawowe parametry geometryczne pokazano na rys. 1 .

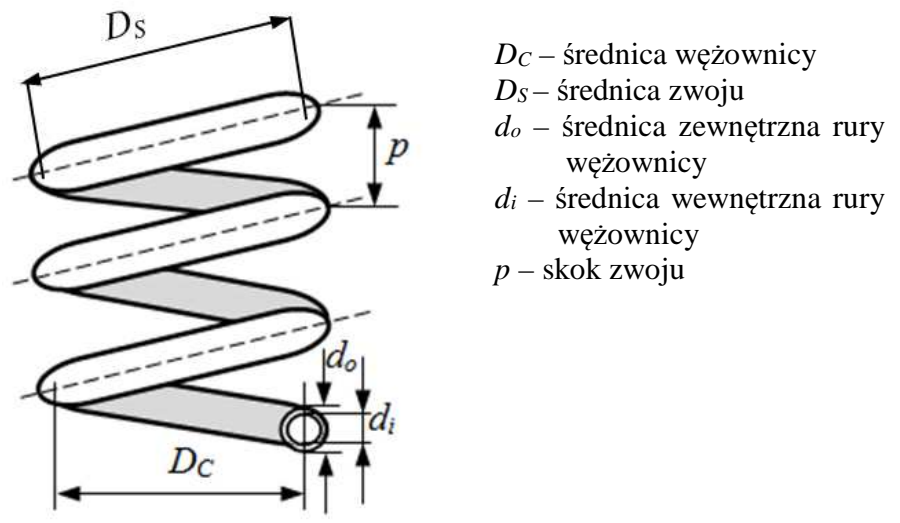

Rys. 1. Geometria wężownicy

Fig. 1. Coil geometry

Średnica $D_{C}$ wężownicy zależy od średnicy zwoju wężownicy $D_{S}$ oraz skoku zwoju $p$ w następujący sposób:

$$
D_{C}=\sqrt{D_{S}^{2}-\left(\frac{p}{2 \cdot \pi}\right)^{2}}
$$

podczas gdy średnica zwoju

$$
D_{s}=\frac{L_{S}}{N \cdot \pi}
$$

gdzie $L_{S}$ jest całkowitą długością rury wężownicy, a $N$ stanowi liczbę zwojów.

$\mathrm{Z}$ kolei całkowita długość rury wężownicy jest wyrażona wzorem

$$
L_{s}=N \cdot 2 \cdot \pi \cdot \sqrt{\frac{D_{C}^{2}}{4}+\left(\frac{p}{2 \cdot \pi}\right)^{2}}
$$


Natomiast wysokość wężownicy

$$
H_{S}=N \cdot p
$$

Wymiarem charakterystycznym, używanym w obliczeniach związanych z procesem wymiany ciepła na zewnątrz wężownicy, jest parametr $D$ opisany następującym wzorem:

$$
D=D_{s} \cdot\left[1+\left(\frac{p}{\pi \cdot D_{s}}\right)\right]
$$

$\mathrm{W}$ analizie wymiany ciepła w wężownicach wykorzystuje się również tzw. współczynnik krzywizny $\delta$, który jest zdefiniowany jako

$$
\delta=\frac{d_{i}}{D_{C}}
$$

\section{Liczba Deana i krytyczna liczba Reynoldsa}

Głównym czynnikiem wpływającym na intensyfikację wymiany ciepła w wężownicy jest pojawienie się przepływu wtórnego generowanego wewnątrz zakrzywionej rury, który jest efektem interakcji siły odśrodkowej, siły bezwładności oraz sił lepkości. Powoduje to pojawienie się złożonego przepływu wtórnego, w płaszczyźnie prostopadłej do przepływu głównego, który istotnie przyczynia się do intensyfikacji wymiany ciepła.

Koncepcja wykorzystania spiralnej geometrii w wymiennikach ciepła pojawiła się pod koniec IX w. [1]. Pierwsze prace poświęcone badaniom przepływu w zakrzywionych kanałach były zapoczątkowane na przełomie IX i XX w. przez Thomsona [2], Grindleya [3], Williamsa [4] i Eustica [5, 6]. W pracach [2, 3] zaobserwowano, że zakrzywienie kanału ma istotny wpływ na przepływ płynu. Z kolei autorzy [4] odnotowali, że w kanale zakrzywionym występuje przesunięcie maksymalnej prędkości osiowej w kierunku ścianki zewnętrznej. Eustice w pracy [5], przy wykorzystaniu wizualizacji przepływu za pomocą iniekcji tuszu, wykazał istnienie przepływu wtórnego. W [6] zaś porównywał przepływ i opory hydrauliczne w zakrzywionych rurach. Wykazał on, że następuje wzrost strat ciśnienia w rurach zakrzywionych w porównaniu do rur prostych.

Eksperymentalną analizę oporów przepływu w rurach zakrzywionych badał również White [7], który określił prędkość krytyczną, przy której występuje przepływ turbulentny. Stwierdził, że w rurach zakrzywionych przejście przepływu laminarnego w turbulentny następuje przy wyższej prędkości niż dla rur prostych. Taylor i Yarrow [8] również badali przejście przepływu laminarnego w turbulentny i potwierdzili wyniki White'a. Na bazie tych eksperymentów ustalili zależność liczby Reynoldsa w funkcji pierwiastka ze współczynnika krzywizny $\delta$, przy której zachodzi przejście przepływu laminarnego w turbulentny. 
Prekursorem badań teoretycznych dotyczących analizy przepływu w rurach zakrzywionych był Dean, który w swojej pierwszej pracy [9] analizował laminarny nieściśliwy przepływ w zakrzywionej rurze w oparciu o równania Naviera Stokesa. Na bazie hipotezy o małych krzywiznach wykazał istnienie przepływów wtórnych oraz dwóch przeciwbieżnych wirów (tzw. wirów Deana), co zostało eksperymentalnie potwierdzone $\mathrm{w}[8,11,13]$ oraz teoretycznie $\mathrm{w}$ pracy [12]. Przedstawione w [9] rozwiązanie jakościowo poprawnie opisywało zjawisko przepływu w zakrzywionych rurach, jednak nie uwzględniało związku pomiędzy gradientem ciśnienia a prędkością. W pracy [10] Dean rozszerzył analizę i zapisując w cylindrycznym układzie współrzędnych równania Naviera Stokesa, zbudował układ równań (zwany równaniami Deana) oraz określił, wyprowadzony na drodze teoretycznej, związek między gradientem ciśnienia a prędkością. Efektem tych analiz były również nowe parametry $K$ i $C$ występujące w równaniach Deana [10]:

$$
K=2 \cdot w_{o}{ }^{2} \cdot \frac{r_{i}^{3}}{a \cdot v^{2}}=2 \cdot\left(\frac{w_{o} \cdot r_{i}}{v}\right)^{2} \cdot \frac{r_{i}}{a}
$$

gdzie: $w_{o}$ - prędkość w osi rury, $a=D_{C} / 2-$ promień wężownicy, $v-$ lepkość kinematyczna, $r_{i}-$ promień wewnętrzny rury, oraz

$$
C=G \cdot \frac{a^{2}}{\mu \cdot w_{o}}
$$

gdzie: $G$ - gradient ciśnienia, $\mu$ - lepkość dynamiczna.

Odpowiednie wyskalowanie parametru $C$ umożliwia zapis parametru $K$ w formie [13]:

$$
K=\left(\frac{w_{o} \cdot r_{i}}{v}\right)^{2} \cdot \frac{r_{i}}{a}
$$

Dla małych liczb Reynoldsa [10] można przyjąć:

$$
R e=\frac{w_{o} \cdot r_{i}}{v} \cong \frac{\bar{w} \cdot d_{i}}{v}
$$

gdzie: $\bar{w}$ - prędkość średnia, $d_{i}$ - średnica wewnętrzna rury.

Zatem równanie (9) sprowadza się do postaci

$$
K=R e^{2} \cdot \frac{r_{i}}{a}=R e^{2} \cdot \frac{d_{i}}{D_{C}}
$$

Jako pierwszy liczbę podobieństwa (nazwaną liczbą Deana), w postaci wzoru (12), w analizie przepływów zastosował White [7]:

$$
D e=\sqrt{K}=R e \cdot \sqrt{\frac{d_{i}}{D_{C}}}=R e \cdot \sqrt{\delta}
$$


Liczba Deana (12) określa związek pomiędzy siłami bezwładności, odśrodkowymi i lepkości oraz jest wskaźnikiem charakteryzującym stabilność przepływu w kanałach zakrzywionych, co udowodnił Reid w swojej pracy [12]. Potwierdził on, że po przekroczeniu pewnej krytycznej wartości liczby Deana $D e>36$ przepływ w kanałach zakrzywionych staje się niestabilny i pojawiają się przepływy wtórne oraz przeciwbieżne wiry. Ponadto w odróżnieniu od wyników Deana [9], w których wiry są symetryczne, Reid wykazał wystąpienie ich pewnej asymetrii. McConalogue oraz Srivastava [14] kontynuowali i rozwinęli badania nad przepływami w przewodach zakrzywionych prowadzone przez Deana w [10]. Autorzy opracowali metode wykorzystującą rozwinięcie w szereg Fouriera w odniesieniu do kąta biegunowego w płaszczyźnie przekroju rury, a wynikowe sprzężone równania, będące uproszczoną formą równań Naviera Skokesa, rozwiązali numerycznie. Wprowadzili nieco zmodyfikowaną wersję liczby Deana w postaci:

$$
D n=4 \cdot \sqrt{2} \cdot D e
$$

Potwierdzili, że liczba Deana może być stosowana w analizie przepływu w kanałach zakrzywionych jedynie dla małych jej wartości oraz udowodnili, że pojawienie się symetrycznych sprzężonych wirów występuje również przy małych wartościach liczby Deana. Dla $D n<100$ [17] liczba $D n$ jest proporcjonalna do $D e$, zaś dla dużych wartości związek pomiędzy $D n$ i $D e$ staje się nieliniowy. Jest to efekt utraty liniowej zależności pomiędzy gradientem ciśnienia a objętościowym wydatkiem przepływu płynu $[15,16]$. Dlatego dla dużych wartości liczb Deana jest stosowana odmienna wersja liczby Deana w postaci $[15,16,18]$ :

$$
D n=\frac{G \cdot r_{i}^{3}}{\mu \cdot v} \cdot \sqrt{\frac{2 \cdot r_{i}}{a}}
$$

Kluczowym czynnikiem wpływającym na warunki wymiany ciepła podczas przepływu w rurach zakrzywionych oraz na przejście przepływu laminarnego w turbulentny jest liczba Reynoldsa zdefiniowana w formie (10), która po raz pierwszy jako kryterium przejścia przepływu laminarnego w turbulentny dla rur prostych przy wykorzystaniu barwnika do wizualizacji przepływu została zaproponowana w pracy [19]. Reynolds w [19] zasugerował jej wartość na poziomie $R e=2100$ dla górnej granicy przepływu laminarnego. Jednak zarówno w rurach prostych, jak i zakrzywionych nie występuje bezpośrednie i jednoznaczne przejście pomiędzy przepływem laminarnym a turbulentnym. Już Reynolds na podstawie własnych badań zaobserwował, że utrzymanie przepływu laminarnego jest możliwe do wartości nawet $R e=12000$ przy redukcji zewnętrznych zaburzeń przepływu do minimalnych wartości. Eckman w pracy [20] utrzymał przepływ laminarny do wartości liczby Reynoldsa $R e=40000$. Dla rur prostych autorzy prac $[20,21,22]$ wnioskują, że przepływ staje się turbulentnym przy pewnej krytycznej liczbie Reynoldsa w zakresie 2000-100 000, przy czym jest to uzależnione od tzw. „gładkości” wlotu do rury, jednak nie pozwala na wyjaśnienie tak 
szerokiego zakresu przejścia przepływu laminarnego w turbulentny. Z kolei Rotta [23] w badaniach eksperymentalnych ustalił przejście przepływu laminarnego dla liczby Reynoldsa w zakresie 2000-3000. Zatem proces ten obejmuje pewien zakres liczb Reynoldsa, w którym występuje tzw. obszar przejściowy.

Dla rur zakrzywionych przejście przepływu laminarnego w turbulentny odbywa się przy większych liczbach Reynoldsa niż dla rur prostych, co już spostrzegli White [7] oraz Taylor i Yarrow [8] w swoich pracach. Taylor i Yarrow zaobserwowali, że dla $\sqrt{\delta}=0,232$ najwyższa wartość liczby Reynoldsa, przy której przepływ jest jeszcze laminarny, wynosi 5830 , zaś dla $\sqrt{\delta}=0,177$ jest ona równa 5010. Dla $\sqrt{\delta}=0,232$ najniższa liczba Reynoldsa, przy której przepływ jest jeszcze burzliwy, jest równa 7100, natomiast dla $\sqrt{\delta}=0,177$ wynosi ona 6350 . Zakrzywienie przewodu przyczynia się stabilizacji przepływu laminarnego, w porównaniu do rur prostych, co zaobserwowali Sreenivasan i Strykowski [24], dlatego przejście do przepływu turbulentnego odbywa się przy większych liczbach Reynoldsa. Poza tym jak zaobserwowali Sreenivasan i Strykowski, krytyczna liczba Reynoldsa, przy której pojawia się przejście w przepływ turbulentny, osiąga maksimum, a potem spada wraz ze wzrostem krzywizny [24]. Dla $\delta=0,039$ przepływ laminarny jest jeszcze możliwy dla liczby Reynoldsa równej 5200 (rys. 2.).

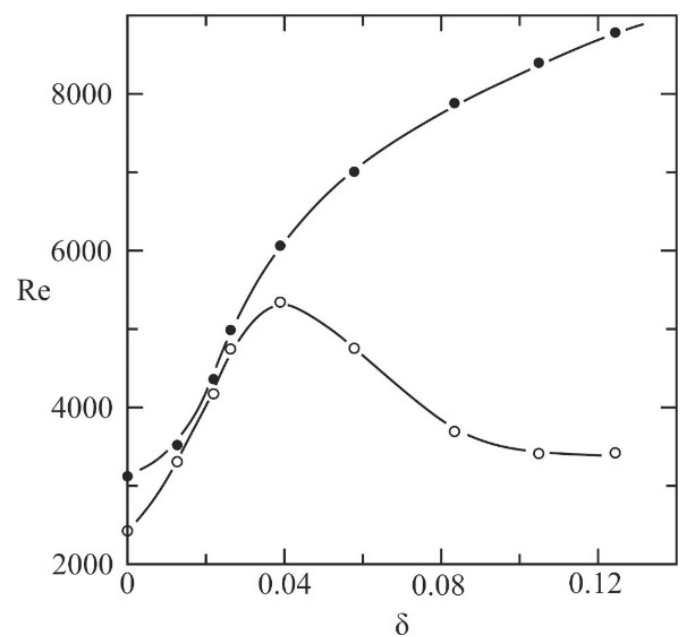

Rys. 2. Krytyczne liczby Reynoldsa ( ${ }^{\circ}-$ dolna, $\bullet$ - górna)

Fig. 2. Critical Reynolds numbers $\left({ }^{\circ}-\right.$ the lower, $\bullet$ - the upper)

Webster i Humphrey [27] w przeprowadzonych badaniach eksperymentalnych ustalili, że występującym w środkowej części rdzenia strumienia niskoczęstotliwościowym oscylacjom przepływu towarzyszy uwarstwiony ruch w pobliżu ścianek zewnętrznych w zakresie liczb Reynoldsa $5060<R e<6330$ oraz $\delta=0,055$. Autorzy sugerują, że inicjatorem turbulizacji (niestabilności) przepływu jest środkowa część rdzenia strumienia płynu. Identyfikacja przejścia przepływu laminarnego w turbulentny w przewodach zakrzywionych jest utrudniona 
$\mathrm{z}$ uwagi na fakt, że proces ten zachodzi stopniowo i pomiędzy przepływem laminarnym a turbulentnym jest obszar przejściowy [24-26]. Zatem przejście pomiędzy przepływem laminarnym a turbulentnym charakteryzują dwie krytyczne liczby Reynoldsa - dolna i górna. Pierwsze kryterium określające krytyczną liczbę Reynoldsa jako granicę przejścia pomiędzy przepływem uwarstwionym a turbulentnym zostało wprowadzone przez Ito [28] na podstawie badań eksperymentalnych, dla $15<\delta^{-1}<860$ :

$$
R e_{\text {crit }}=20000 \cdot \delta^{0,32}
$$

Z kolei nieco później Srinivasan [29, 30] rekomendował korelację na krytyczną liczbę Reynoldsa w postaci:

$$
R e_{\text {crit }}=2100 \cdot\left(1+12 \cdot \delta^{0,5}\right)
$$

ważnej dla $\delta^{-1}<200$, która była później zweryfikowana eksperymentalnie w pracy [31]. Schmidt [32] przedstawił zależność na krytyczną liczbę Reynoldsa w postaci:

$$
R e_{c r i t}=2300 \cdot\left(1+8,6 \cdot \delta^{0,45}\right)
$$

dla $\delta^{-1}<200$.

Kubair i Varrier w pracy [33] na podstawie badań eksperymentalnych dla rur helikoidalnych dla zakresu $9,7<\delta^{-1}<2000$ ustalili korelację określającą przejście przepływu laminarnego $\mathrm{w}$ turbulentny

$$
R e_{c r i t}=12730 \cdot \delta^{0,32}
$$

Wojtkowiak i Oleśkiewicz-Popiel [34] w oparciu o własne badania dla rur helikoidalnych przedstawili zależność na krytyczną liczbę Reynoldsa:

$$
R e_{\text {crit }}=2300 \cdot\left(1+12 \cdot \delta^{0,58}\right)
$$

ważną dla $\delta^{-1}<205$.

Z kolei Mishra i Gupta w pracy [35], dla rur helikoidalnych w korelacji na krytyczną liczbę Reynoldsa, uwzględnili skok zwoju:

$$
R e_{\text {crit }}=20000 \cdot\left[\frac{\delta}{\left(1+\frac{P}{2 \cdot \pi \cdot a}\right)^{2}}\right]^{0,32}
$$

Przedstawiona zależność jest ważna dla $\delta^{-1} \geq 10$. Mishra i Gupta zauważyli, że wraz ze wzrostem skoku zwoju $P$ maleje wartość krytycznej liczby Reynoldsa, przy którym zachodzi przejście przepływu laminarnego w turbulentny. Dla $p=0$ wzór (20) jest tożsamy z korelacją podaną przez Ito. 
Autorzy prac [36, 37] dokonali podziału wężownic w zależności od krzywizny i na podstawie badań eksperymentalnych ustalili następujące korelacje:

- dla wężownic o dużej krzywiźnie, tj. $\delta^{-1}<24$

$$
R e_{\text {crit }}=30000 \cdot \delta^{0,47}
$$

- dla wężownic o średniej krzywiźnie $30 \leq \delta^{-1} \leq 110$

$$
\begin{aligned}
& R e_{\text {crit }}=12500 \cdot \delta^{0,31} \\
& R e_{\text {crit }}=120000 \cdot \delta^{0,57}
\end{aligned}
$$

- dla wężownic o małej krzywiźnie $\delta^{-1} \geq 150$

$$
\operatorname{Re}_{\text {crit }}=2300 \cdot\left(1+210 \cdot \delta^{1,12}\right)
$$

W wymiennikach spiralnych krzywizna ulega zmianie, zatem przejście $\mathrm{z}$ przepływu laminarnego odbywa się w pewnym zakresie liczb Reynoldsa. W takim przypadku Srinivasan [30] zaleca wyznaczanie krytycznych liczb Reynoldsa $R e_{\max }$ i $R e_{\min }$ przy wykorzystaniu formuły (16) dla $\delta_{\min }=\frac{d_{i}}{D_{C \max }}$ oraz $\delta_{\max }=\frac{d_{i}}{D_{C \min }}$. Przejście przepływu laminarnego w turbulentny ma miejsce pomiędzy $R e_{\min }$ i $R e_{\max } . \mathrm{Z}$ kolei autorzy pracy [38] zalecają dla wymienników spiralnych stosowanie średniej arytmetycznej średnicy $D_{C s ́ r}=0,5 \cdot\left(D_{C \min }+\right.$ $\left.+D_{\operatorname{Cmax}}\right)$ jako wymiaru charakterystycznego dla wyznaczania krytycznej liczby Reynoldsa.

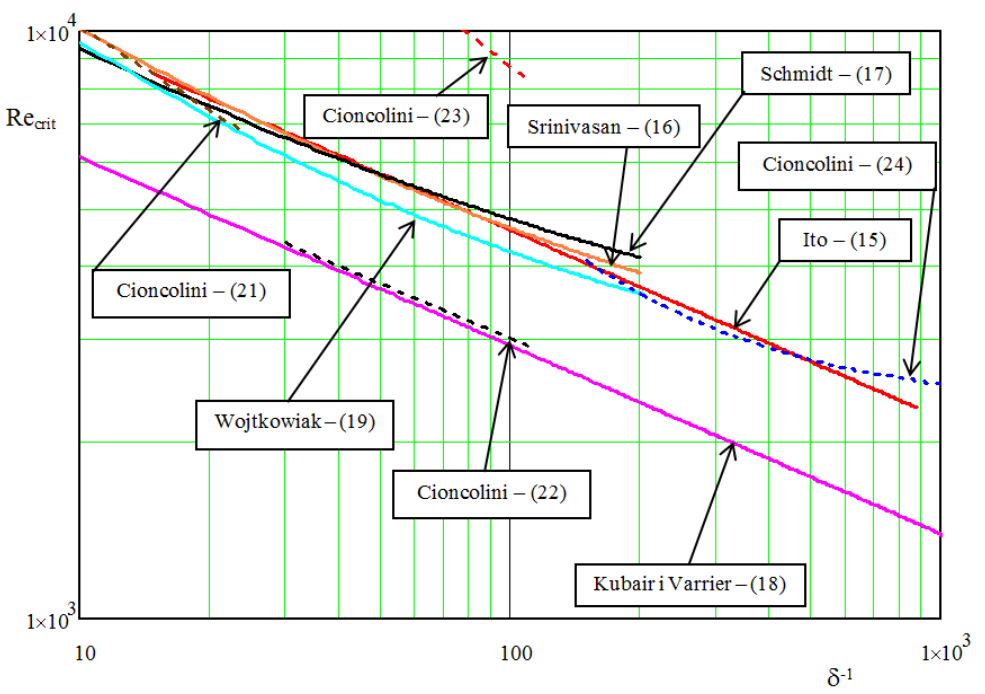

Rys. 3. Krytyczna liczba Reynoldsa w funkcji współczynnika krzywizny

Fig. 3. Critical Reynolds number in function of curvature coefficient 


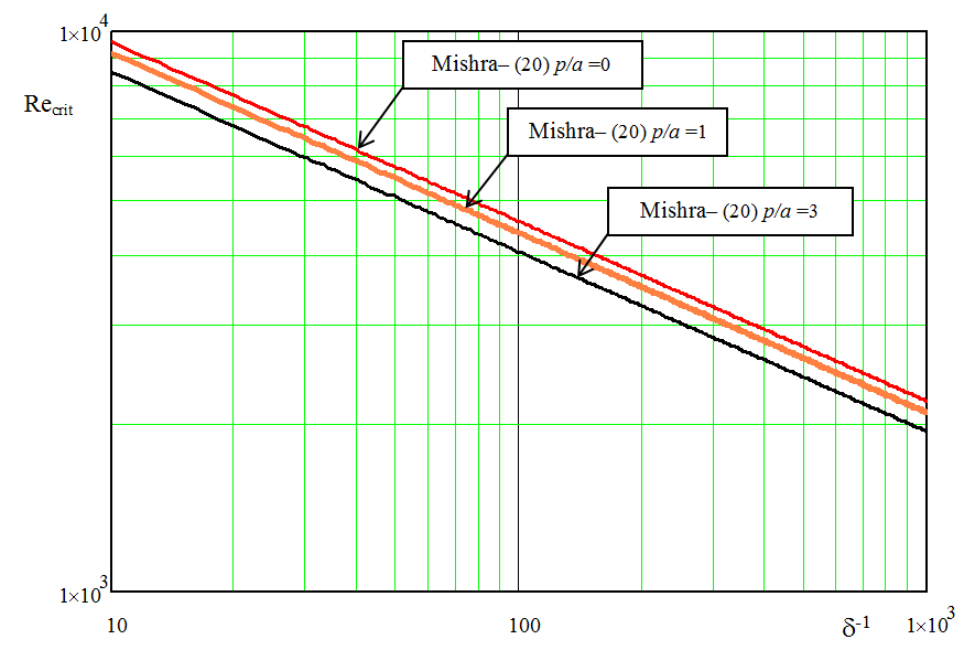

Rys. 4. Krytyczna liczba Reynoldsa w zależności od geometrii wężownicy

Fig. 4. Critical Reynolds number in relation to coil geometry

Na rysunku 3. przedstawiono estymację krytycznej liczby Reynoldsa przy wykorzystaniu różnych korelacji. Zaś wpływ relacji skoku zwoju do promienia wężownicy na podstawie korelacji (20) Mishry i Gupty pokazuje rys. 4. W zależnościach określonych wzorami (16), (17), (19) oraz (24), przy krzywiźnie dążącej do zera, liczba Reynoldsa dąży do wartości odpowiadającej rurom prostym. Cioncolini i Santini $[36,37]$ dla wężownicy o średniej krzywiźnie, tj. gdy $30 \leq \delta^{-1} \leq$ $\leq 110$, ustalili dwie różne korelacje (22) i (23). Jest to związane z nieciągłością wartości współczynnika tarcia podczas przejścia z przepływu laminarnego do turbulentnego. $\mathrm{W}$ odniesieniu do rur prostych jest to związane z nieciągłością pomiędzy korelacją Hagen-Poiseuilla a funkcją określającą współczynnik tarcia dla przepływu turbulentnego. Przy czym dla wężownic helikoidalnych, w odróżnieniu od rur prostych, Cioncolini i Santini jako pierwsi zaobserwowali wystąpienie dwu nieciągłości współczynnika tarcia [36]. Autorzy [36, 37] sugerują, że dla przepływów charakteryzujących się wystąpieniem pierwszej nieciągłości dla liczb Reynoldsa, wskazujących na przejście z laminarnego do turbulentnego przepływu, bardziej adekwatne jest stosowanie korelacji (22). Zaś dla przepływów, w których liczby Reynoldsa wskazują na wystąpienie drugiej nieciągłości współczynnika tarcia w rurach helikoidalnych, autorzy [36] zalecają stosowanie korelacji (23).

\section{Podsumowanie}

Wężownicowe wymienniki ciepła stosowane obecnie w różnych gałęziach przemysłu wymagają, w opisie zjawisk niezbędnych przy projektowaniu, uwzględnienia liczb kryterialnych związanych $\mathrm{z}$ charakterem przepływu w rurze 
wężownicy. Są to: krytyczna liczba Reynoldsa oraz liczba Deana. Intensyfikacja wymiany ciepła zachodzącej $\mathrm{w}$ rurze wężownicy jest powodowana przede wszystkim pojawiającymi się przepływami wtórnymi będącymi efektem interakcji pomiędzy siłami odśrodkowymi, bezwładności i siłami wywołanymi lepkością. Zjawiska te, opisane skomplikowanymi równaniami różniczkowymi, zostały, poprzez zastosowanie analizy wymiarowej, uporządkowane i uproszczone dzięki wymienionym wcześniej liczbom bezwymiarowym. Zaprezentowany $\mathrm{w}$ artykule przegląd literaturowy oraz analiza porównawcza systematyzuje wiedzę niezbędną przy obliczeniach wężownicowych wymienników ciepła z uwzględnieniem liczby Deana i krytycznej liczby Reynoldsa. Uporządkowano również zakres stosowalności odpowiednich wzorów kryterialnych. Jest to o tyle istotne, że zarówno postać liczby Deana, jak i wartość krytycznej liczby Reynoldsa są uzależnione od parametrów geometrycznych wężownicy oraz zmiennego charakteru przepływu płynu. Przedstawione rozważania pozwalają lepiej zrozumieć charakter zjawisk występujących przy konwekcyjnym przepływie w zakrzywionych rurach.

\section{Literatura}

[1] Boothroyd A.: Spiral Heat exchanger, International Encyclopedia of Heat and Mass Transfer, ed. G. Hewitt, Y. Pulezhaev, CRC Press, N.Y. 1997, p. 1044.

[2] Thomson J.: On the origin of windings of rivers in alluvial plains, with remarks on the flow of water round bends in pipes, Proc. Royal Society of London, 25 (1877) 5-8.

[3] Grindley J.H., Gibson A.H.: On the Frictional Resistance to the flow of Air through a Pipe, Proc. Royal Society of London, London 1908, pp. 114-139.

[4] Williams G.S., C.W. Hubbel, G.H. Fenkell: Experiments at Detroit, Mich., On the effect of curvature upon the flow of water in pipes, Trans. American Society Civil Eng., 47 (1902) 1-196.

[5] Eustice J.: Experiments on streamline motion in curved pipes, Proc. Royal Society of London, Series A, 85 (1911) 114-139.

[6] Eustice J.: Flow of water in curved pipes, Proc. Royal Society of London, Series A, 84 (1910) 107-118.

[7] White C.M.: Streamline flow through curved pipes, Proc. Royal Society of London, Serial A, 123 (1929) 645-663.

[8] Taylor G.I., Yarrow F.R.S.: The criterion for turbulence in curved pipes, Proc. Royal Society of London, Serial A, 124 (1929) 243-249.

[9] Dean W.R.: Note on the motion of fluid in a curved pipe, Phil. Mag., 4 (1927) 208.

[10] Dean W.R.: The stream-line motion of fluid in a curved pipe, Phil. Mag., 5 (1928) 673.

[11] Brewster D.B., Grosberg P., Nissan A.H.: The stability of viscous flow between horizontal concentric cylinders, Proc. Royal Society of London, Series A, 251 (1959) 76-91. 
[12] Reid W.H.: On the stability of viscous flow in a curved channel, Proc. Royal Society of London, Series A, Math. Physical Sci., 244 (1958) 186-198.

[13] Mestel J.: Flow in curved pipes: The Dean equations, Lecture Handout for Course M4A33, Imperial College.

[14] McConalogue D.J., Srivastava R.S.: Motion of a fluid in a curved tube, Proc. Royal Society of London, Series A, 307(1968) 37-53.

[15] Van Dyke M.: Extended Stokes Series: Laminar flow through a loosely coiled pipe, J. Fluid Mech., 86 (1978) 129-145.

[16] Yanase S., Goto N., Yamamoto K.: Dual solutions of the flow through a curved tube, Fluid Dyn. Res., 5 (1989) 191-201.

[17] Cieślicki K., Piechna A.: Can the Dean number alone characterize flow similarity in differently bent tubes?, J. Fluids Eng., 134 (2012) 051205.

[18] Md. Mainul Hoque, Md. Mahmud Alam: Effects of Dean number and curvature on fluid flow through a curved pipe with magnetic field, Procedia Eng., 56 (2013) 245-253.

[19] Reynolds O.: An experimental investigation of the circumstances which determine whether the motion of water shall be direct or sinuous, and of the law of resistances in parallel channels, Phil. Trans. Roy. Soc. London, 174 (1883) 935-982.

[20] Ekman V.W.: On the change from steady to turbulent motion of liquids, Ark. Mat. Astron. Fys., 6 (1911) 1-16.

[21] Schiller L.: Neu Berichte zur Turbulenzentwicklung, Z. Angew. Math. Mech., 14 (1934) 36-42.

[22] Pfenniger W.:Transition in the inlet length of tubes at high Reynolds numbers. In Boundary Layer and flow control, ed. G.V. Lachman, Pergamon, New York 1961, pp. 970-980.

[23] Rotta J.: Experimenteller Beitrag zur Entstehung Turbulenter Stromung im Rohr, Ing-Arch., 24 (1956) 258-281.

[24] Sreenivasan K.R., Strykowski P.J.: Stabilization effects in flow through helically coiled pipes, Experiments Fluids, 1 (1983) 31-36.

[25] Kakac S., Shah R.K., Aung W.: Handbook of Single-Phase Convective Heat Transfer, Wiley-Interscience, Hoboken, NJ, 1987.

[26] Schmidt E.F.: Wärmeübergang und Druckverlust in Rohrschlangen, Z. Technische Chemie, 39 (1967) 781-789.

[27] Webster D.R., Humphrey J.A.C.: Experimental observations of flow instabilities in a helical coil, ASME J. Fluids Eng., 115 (1993) 436-443.

[28] Ito H.: Friction factors for turbulent flow in curved pipes, ASME J. Basic Eng. Trans., 81 (1959) 123-132.

[29] Srinivasan P.S., Nadapurkar S.S., Holland F.A.: Pressure drop and heat transfer in coils, Chemical Eng. J., 218 (1968) 113-119.

[30] Srinivasan P.S., Nadapurkar S.S., Holland F.A.: Friction factors for coils, Trans. Institution Chemical Eng., 48 (1970) T156-T161.

[31] Kalb C.E., Seader J.D.: Entrance region heat transfer in a uniform wall-temperature helical coil with transition from turbulent to laminar flow, Int. J. Heat Mass Transfer, 26 (1983) 23-32. 
[32] Schmidt D.F.: Wärmeübergang and Druckverlust in Rohrshlangen, Chemical Eng. Technol., 13 (1967) 781-789.

[33] Kubair V., Varrier C.B.S.: Pressure drop for fluid flow in helical coils, Trans. Indian Inst. Chem. Eng., 14 (1961) 93-97.

[34] Wojtkowiak J., Oleśkowicz-Popiel C.: Współczynnik oporu przepływu dla rury helikoidalnej, Inż. Chemiczna Procesowa, 2 (1995) 273-281.

[35] Mishra P., Gupta S.N.: Momentum transfer in curved pipes 1. Newtonian Fluids; 2. Non-Newtonian Fluids, Industrial Eng. Chemistry Process Design Development, 18 (1979) 130-142.

[36] Cioncolini A., Santini L.: An experimental investigation regarding the laminar to turbulent flow transition in helically coiled pipes, Exp. Thermal and Fluid Sci., 30 (2006) 367-380.

[37] Cioncolini A., Santini L.: On laminar to turbulent flow transition in adiabatic helically coiled pipe flow, Exp. Thermal Fluid Sci., 30 (2006) 653-661.

[38] Kubair V., Kuloor N.R.: Flow of Newtonian fluids in Archimedean spiral tube coils: Correlation of laminar, transition and turbulent flows, Indian J. Technol., 4 (1966) 3-8.

\section{CRITERION NUMBERS IN CHARACTERISTICS OF A COIL HEAT EXCHANGER}

\section{Sum mary}

The article presents a literature review and a comparative analysis of criterion numbers important in the description and design of coil heat exchangers - the Dean number and the critical Reynolds number. These numbers take into account the specificity of fluid flow in the coil resulting from winding of the circular section pipe on the cylindrical side. Coil geometry necessary in the description of criterion numbers was also discussed due to the significant influence of geometric parameters on the flow structure. The work analyzes the scope of applicability of appropriate criterion formulas in the description of phenomena related to intensification of heat transfer in the coil heat exchanger resulting from the occurrence of secondary flow, which is the effect of interaction of centrifugal forces, inertia forces and forces caused by fluid viscosity.

Keywords: coil, Dean number, critical Reynolds number

DOI: $10.7862 / \mathrm{rm} .2019 .06$

Otrzymano/received: 31.05 .2019 r.

Zaakceptowano/accepted: 14.07.2019 r. 